\title{
Gender-based differences in the high-risk sexual behaviours of young people aged 15-29 in Melilla (Spain): a cross-sectional study
}

\author{
Esperanza Romero-Estudillo ${ }^{1 \dagger}$, Emilio González-Jiménez ${ }^{1 * \dagger}$, María C Mesa-Franco ${ }^{2}$ and Inmaculada García-García ${ }^{3}$
}

\begin{abstract}
Background: Research confirms the existence of gender-based differences regarding the high-risk sexual behaviour (non-use of condoms and casual partners) of young men and women. The objectives were to provide evidence for this association; to analyse the reasons why both sexes have sexual relations with casual partners and to ascertain the motives for condom use or non-use during casual sex.

Methods: A cross-sectional study was performed on a sample of 900 participants, 524 males and 376 females. All participants were 15-29 (20.93 \pm 4.071) years of age and came from four different centres (a university, two secondary schools, and a military base) in Melilla (Spain). The participants were given a socio-demographic survey as well as a psychometric text on high-risk sexual behaviour.

Results: The results found gender-based significant differences for sexual relations with penetration ( $p=0.001)$, number of sexual partners $(p=0.001)$, and sexual relations with casual partners $(p=0.001)$. In all of these variables, male participants had higher percentages than female participants. Reasons for having casual sexual relations were also different for men and women, differences were found for the items, opportunity $(p=0.001)$, interest in knowing the other person $(p=0.015)$, physical excitement $(p=0.056)$ and drug consumption $(p=0.059)$. Regarding the reasons for consistent condom use with casual partners, there were differences for the item, my demand of a condom ( $p=0.002)$. For the non-use of condoms with casual partners, differences were found for the items, I do not like to use condoms ( $p=0.001)$ and condoms lessen sensitivity and reduce pleasure $(p=0.009)$.

Conclusions: Men and women were found to have different high-risk sexual behaviours and practices. Of the motives for having sexual relations with casual partners, male participants considered opportunity and interest in knowing the other person to be more important than the female participants. Regarding condom use, the female participants' demand to use a condom was a significant gender-based difference. In contrast to the young women, the male participants mostly justified not using a condom because it lessened sensitivity and reduced pleasure.
\end{abstract}

Keywords: Gender, Sexual behaviour, Risk behaviour, Young people

\section{Background}

Research suggests that males and females express their sexuality differently [1] and behave differently when engaging in high-risk sexual practices. More specifically, young men tend to become sexually active earlier. They also have a higher number of casual partners than young women [2]. In contrast, females usually have sexual

\footnotetext{
* Correspondence: emigoj@@ugr.es

${ }^{\dagger}$ Equal contributors

'Department of Nursing, Faculty of Nursing, C/ Santander N ${ }^{\circ} 1$ (52071),

University of Granada, Melilla, Spain

Full list of author information is available at the end of the article
}

relations within the context of a stable committed relationship, which is associated with love and trust [3]. They seem to feel a greater need of a stable partner to have sexual relations and tend to place a greater value on his/her faithfulness [4]. Women also tend to value affection and social position, whereas for men physical attractiveness is important [4]. In the same line, Larrañaga et al. [5] found that Spanish university students have gender-based sexual attitudes that make them reluctant to use contraceptive methods, particularly condoms. An increase in macho as well as romantic attitudes in young 
people appears to contribute to the rejection of preventive measures in sexual relations.

According to Falah-Hassani et al. [6], young women tend to be better informed about the risks of oral contraceptives (e.g. venous thromboembolic diseases) than their male counterparts. Hooke et al. [7] found that 73\% of young women took charge of the use of contraceptives in contrast to $46 \%$ of young men. In addition, males did not have a negative perception of casual sex. This type of sexual relation occurs between people who are strangers or who are only slightly acquainted with each other [8].

According to García-Carpintero et al. [9], barrier contraceptives (e.g. condoms) are more frequently used by males and adolescents, mainly at the beginning of sexual relations with a casual partner. Moreover, the fact that the condom is considered to be a male contraceptive signifies that man tend to use it more than women.

The study conducted by Rodríguez Carrión et al. [10] on sexual behaviours in a sample of 2,225 adolescents found that condoms were the most frequently used contraceptive followed by birth control pills. Of the sexually active participants, $2 \%$ used no contraceptive method, $4 \%$ used the withdrawal method, and $16.6 \%$ reported using the morning-after pill.

Hooke et al. [7] also identified gender-related differences regarding the avoidance of pregnancy to explain the fact that females assumed greater responsibility for birth control than males. Other factors that influenced high-risk sexual practices (non-use of condom and casual partners) included the existence of physical attraction or of an affective relationship. Also mentioned were the level of sexual excitement during relations and the consumption of stimulants such as alcohol or drugs [11,12].

With regard to protection (STIs and pregnancy), Planes et al. [13] reported that the increased use of oral contraceptives has led to a corresponding decrease in the use of condoms. This suggests that young people, in particular, women, are more worried about avoiding pregnancy than about becoming infected with the human immunodeficiency virus (HIV) or contracting a sexually transmitted infection (STI). This indicates that young people believe that the main problem related to their sexuality is risk of pregnancy. Another explanation for the non-use of condoms could be the existence of a stable relationship.

One of the main reasons given by the participants for not using condoms included the lessening of sensitivity and sexual pleasure as well as the fear of being rejected by one's partner because of a lack of trust [14]. This situation has contributed to a dramatic rise in the prevalence of STIs in the youth and adult population. Other practices that could explain this situation are oral and anal sex $[15,16]$.
In fact, it is estimated that there are 333 million new cases in the world each year [17-19]. In recent years, the prevalence of STIs in adolescents living in the city of Melilla, Spanish exclave on the coast of North Africa, has soared. According to data published in the first semester of 2012 by the National Institute of Statistics (Spain) [20], there are 90 diagnosed cases of HIV, due to injection drug use (62.2\%), heterosexual contact (17.7\%), and homosexual contact involving men having sex with men (MSM) (10.2\%). Other transmission categories are blood transfusion $(2.2 \%)$ and mother-to-child vertical transmission (2.2\%). Of the patients diagnosed, $78.8 \%$ are males and $21.1 \%$ are females.

Furthermore, according to the Ministry of Health and Social Policy in Spain [21], in 2012 there were 109 voluntary interruptions of pregnancy (VIPs) in Melilla. Ten of these cases were females 15-19 years of age; 36 cases were females 20-24 years of age; 31 were females 25-29 years of age; and 32 were females $30-44$ years of age. Most of the women were single, and $30.27 \%$ had had at least one previous VIP. Interestingly, in Ceuta, a Spanish city also located in North Africa, whose sociodemographic and cultural characteristics are very similar to those of Melilla, there were only 38 cases of VIPs during the same time period. This difference in the number of VIPs is one of the reasons why it was decided to investigate sexual behaviour in Melilla.

The steadily increasing prevalence of STIs in people of younger ages underlines the need to examine the aspects involved in the adoption of high-risk sexual practices, based on gender [22]. Accordingly, the first objective of this study was to identify a possible association between gender and high-risk sexual practices. The second objective was to analyse the motives of both males and females for having sexual relations with casual partners. The third was to determine the aspects that conditioned condom use or non-use in casual sex.

\section{Methods}

\section{Study design and sampling}

A cross-sectional study was carried out in Melilla at two secondary schools, a branch of the National Distance Education University (UNED), the campus of the University of Granada, and a Spanish military base. In order to calculate optimal sample size, we consulted the ongoing census of the National Institute of Statistics (Spain), for 1 January 2013 [23]. According to the census data, Melilla has 17,998 residents that are 15-29 years of age [24]. Assuming an error of $3 \%$, it was estimated that our study required a sample population of approximately 1000 participants of 15-29 years of age. The sample was finally composed of 900 subjects: 524 males (58.2\%) and 376 females (41.8\%).

All participants were 15-29 (20.93 \pm 4.071$)$ years of age and had previously agreed to answer $80 \%$ of the questions 
in the survey. Participants were excluded if they did not fall into this age range or if they refused to respond to the required number of items.

The study was carried out in three phases. During the first phase (6.5 months), the researchers obtained permission to access the secondary schools, universities, and military base where the data were to be collected. Meetings were held with the directors of each of the centres to explain the objectives of the study and to schedule a date for a meeting with parents or guardians of students under 18. During the second phase of the project (four months), meetings were held with parents or guardians. After an explanation of the study, they were given an informed consent form. During the third phase (six months), the participants were asked to fill out two questionnaires.

Two data collection instruments were used. The first questionnaire collected socio-demographic data (age, gender, marital status, etc.), and the second specifically evaluated psychological variables and the high-risk sexual behaviour of the participants. This instrument, created by Piña et al. [25], is based on Ribes's Psychological Model of Biological Health [26] for the prevention of illnesses. It includes historical and contextual variables (motives, biological states, and social situations) that describe and explain high-risk sexual behaviours. Variables with an impact on sexual behaviour included motivations, substance consumption (alcohol and drugs), and the influence of other individuals. The questionnaire contained 11 demographic items and 28 risk-behaviour items to which the participant could only give one response in the different categories for each item. In the case of the variable sexual relations with penetration, the item did not specify the type of penetration.

There were also 76 questions on contextual variables (i.e. motives, social situations, and biological states) where the participant had the choice of three or four responses. For example, for physical attraction as a motive for having sexual relations with casual partners, participants could enter one of the following response options: Highly determining, Fairly determining, Slightly determining and Not determining. Here, determining was defined as something (in this case, sexual attraction) that contributes to producing a result or behaviour (sexual relations). The modifiers highly, fairly, slightly, and not determining designate a four-point scale.

The conceptual validity of this instrument [25] was obtained by means of exploratory factor analysis with varimax rotation. There were three factors (i.e. readiness for sexual relations, motives for the non-use of condoms, and motives for condom use) with individual values higher than 1, which altogether accounted for $38.36 \%$ of the total variance, In the reliability analysis, the value of Cronbach's alpha was 0.82

\section{Statistical analyses}

A descriptive analysis was performed by using percentages and frequencies for the category variables, mean, and typical deviation in the quantitative variables and contingency tables. A bivariate analysis of these data was performed, using chi-square and Mann-Whitney U tests. $P<0.05$ was considered significant.

\section{Ethics}

This research was performed in strict compliance with the international code of medical ethics established by the World Medical Association and the Declaration of Helsinki. Ethical approval for the conduct of the study was obtained from the University of Granada. Data gathering processes followed standard ethical guidelines. Participants were assured that participation was voluntary and that the information provided by them would be kept completely anonymous and confidential. The participants (15-17 years of age) had the written authorization of their parents or guardians to participate in the study whereas subjects that were 18 and older personally gave their written informed consent.

\section{Results}

The sample population had a mean age of 20.93 years (SD 4.71), and was distributed in the following intervals: $364(40.4 \%)$ of the participants were 15-19 years old; 345 (38.3\%) were 20-24 years old; and 191 (21.2\%) were 25-29 years old. Of these participants, 664 (73.9\%) were students; 137 (15.2\%) were in the armed forces; 33 (3.7\%) had jobs; and 65 (7.2\%) were unemployed.

Regarding sexual practices, according to gender (Table 1), the results showed that $59 \%$ of the participants (of a sample composed of $93.5 \%$ heterosexuals, 3.5\% homosexuals, 3\% bisexuals) had had sexual intercourse with penetration. This was true for $78.7 \%$ of the male participants, which meant that there were statistically significant differences $(p=0.001)$ between the two sexes. In reference to the variable, condom use during the first sexual relation, there were no significant gender differences though a slightly higher percentage of men $(79.1 \%)$ than women $(78 \%)$ reported condom use in the first relation.

With regard to frequency of condom use, no significant differences were found $(p=0.475)$ between sexes. More specifically, $33.9 \%$ of the female participants and $38.1 \%$ of the male participants said that they used a condom most of the time. In reference to number of sexual partners, there were significant differences $(p=0.001)$ between both sexes. A total of $37.9 \%$ of the female participants reported intercourse with only one partner, in contrast to $32.2 \%$ of the male participants who said that they had had eight or more partners.

Significant gender differences were also found for sexual relations with casual partners $(p=0.001)$. In this regard, 
Table 1 High-risk sexual practices, according to gender

\begin{tabular}{|c|c|c|c|c|}
\hline & Total & Females n (\%) & Males n (\%) & $P_{\text {value }}{ }^{\mathrm{a}}$ \\
\hline Sexual relations with penetration & & & & 0.001 \\
\hline Yes & $605(67.2)$ & $309(59)$ & $296(78.7)$ & \\
\hline No & $295(32.8)$ & $215(41)$ & $80(21.3)$ & \\
\hline Condom use during the first sexual relation & & & & 0.767 \\
\hline Yes & $475(78.5)$ & $241(78)$ & $234(79.1)$ & \\
\hline No & $130(21.5)$ & $62(22)$ & $62(20.9)$ & \\
\hline Frequency of condom use: & & & & 0.475 \\
\hline Always & $179(29.8)$ & $84(27.5)$ & $95(32.3)$ & \\
\hline Most of the time & $231(38.5)$ & $119(33.9)$ & $112(38.1)$ & \\
\hline Rarely & $153(25.5)$ & $81(26.5)$ & $72(24.5)$ & \\
\hline Never & $37(6.2)$ & $22(7.2)$ & $15(5.1)$ & \\
\hline Number of sexual partners: & & & & 0.001 \\
\hline Only 1 & $171(28.5)$ & $116(37.9)$ & 55 (18.6) & \\
\hline $2-4$ & $200(33.3)$ & $106(34.6)$ & $94(31.9)$ & \\
\hline $5-7$ & $93(15.5)$ & $42(13.7)$ & $51(17.3)$ & \\
\hline 8 or more & $137(22.8)$ & $42(13.7)$ & $95(32.2)$ & \\
\hline Sexual relations with casual partners: & & & & 0.001 \\
\hline Yes & $290(66.1)$ & $107(55.2)$ & $183(74.7)$ & \\
\hline No & 149 (33.9) & $87(44.8)$ & $62(25.3)$ & \\
\hline Frequency of condom use with a casual partner: & & & & 0.212 \\
\hline Always & $157(53.8)$ & $54(49.1)$ & $103(56.6)$ & \\
\hline Most of the time & $74(25.3)$ & $26(23.6)$ & $48(26.4)$ & \\
\hline Rarely & $46(15.8)$ & $22(20.0)$ & $24(13.2)$ & \\
\hline Never & $15(5.1)$ & $8(7.3)$ & $7(3.8)$ & \\
\hline
\end{tabular}

${ }^{a}$ :using chi-square test.

$55.2 \%$ of the women said that they had engaged in casual sex, in contrast to $74.7 \%$ of the men. For frequency of condom use with casual partners, there were no significant gender-based differences $(p=0.212)$. More specifically, $49.1 \%$ of the female participants and $56.6 \%$ of the male participants said that they always used a condom with casual partners.

With regards to the reasons for having casual sexual relations (Table 2), there were significant gender differences $(p=0.001)$ for the item opportunity. Opportunity in this context is understood as a time or condition favourable for a particular action (e.g. having casual sexual relations). It was found that $38.2 \%$ of the female participants regarded this item as fairly determining, whereas $63.7 \%$ of the males considered it to be very important. Consequently, for both males and females, opportunity was an important reason for engaging in casual sex. Significant differences between men and women were also found for the variable interest in knowing the other person $(p=0.015)$. For $30 \%$ of the women, this variable was slightly determining, whereas for $33.1 \%$ of the men, it was fairly determining.
In relation to physical attraction, there were no significant differences between men and women $(p=0.835)$ since for both, this factor was highly determining. However, in the case of physical excitement, there were significant gender-based differences $(p=0.056)$. In fact, this item was highly determining for $49.1 \%$ of the female participants. In other words, females regarded physical excitement as an important reason for having sexual relations with casual partners. This was also the case for $62.1 \%$ of the male participants.

Alcohol consumption was generally not regarded as influential, as reflected in the lack of significant differences $(p=0.227)$ for both sexes. In reference to this item, $22.7 \%$ of the women and $24.3 \%$ of the men said that it was fairly determining. However, there were significant differences with regards to drug consumption, despite the fact that $84.5 \%$ of the female participants and $77.3 \%$ of the male participants stated that this item was not determining.

In relation to the motives that led to the consistent use of condoms in casual sexual relations (Table 3), $84.5 \%$ of the women and $85.2 \%$ of the men affirmed that 
Table 2 Motives for men and women to have sexual relations with casual partners

\begin{tabular}{|c|c|c|c|c|}
\hline & Total & Females & Males & $P$ value ${ }^{a}$ \\
\hline Opportunity: & & & & 0.001 \\
\hline Highly determining & $144(49.3)$ & $28(25.5)$ & $116(63.7)$ & \\
\hline Fairly determining & $95(32.5)$ & $42(38.2)$ & $53(29.1)$ & \\
\hline Slightly determining & $31(10.6)$ & $25(22.7)$ & $6(3.3)$ & \\
\hline Not determining & $22(7.5)$ & $15(13.6)$ & $7(3.8)$ & \\
\hline Interest in knowing the other person: & & & & 0.015 \\
\hline Highly determining & $61(21)$ & $17(15.5)$ & $44(24.3)$ & \\
\hline Fairly determining & $91(31.3)$ & $31(28.2)$ & $60(33.1)$ & \\
\hline Slightly determining & $77(26.5)$ & $33(30)$ & $44(24.3)$ & \\
\hline Not determining & $62(21.3)$ & $29(26.4)$ & $33(18.2)$ & \\
\hline Physical attraction: & & & & 0.835 \\
\hline Highly determining & $194(66.9)$ & $71(64.5)$ & $123(68.3)$ & \\
\hline Fairly determining & $78(26.9)$ & $64.5(31.8)$ & $43(23.9)$ & \\
\hline Slightly determining & $13(4.5)$ & $3(2.7)$ & $10(5.6)$ & \\
\hline Not determining & $5(1.7)$ & $1(0.9)$ & $4(2.2)$ & \\
\hline Physical excitement: & & & & 0.056 \\
\hline Highly determining & $167(57.2)$ & $54(49.1)$ & $113(62.1)$ & \\
\hline Fairly determining & $97(33.2)$ & $43(39.1)$ & $54(29.7)$ & \\
\hline Slightly determining & $13(4.5)$ & $6(5.5)$ & $7(3.8)$ & \\
\hline Not determining & $15(5.1)$ & $7(6.4)$ & $8(4.4)$ & \\
\hline Alcohol consumption: & & & & 0.227 \\
\hline Highly determining & $38(13.1)$ & $9(8.2)$ & $29(16)$ & \\
\hline Fairly determining & $69(23.7)$ & $25(22.7)$ & $44(24.3)$ & \\
\hline Slightly determining & $64(22)$ & $32(29.1)$ & $32(17.7)$ & \\
\hline Not determining & $120(41.2)$ & $44(40)$ & $76(42)$ & \\
\hline Drug consumption: & & & & 0.059 \\
\hline Highly determining & $20(6.9)$ & $4(3.6)$ & $16(8.8)$ & \\
\hline Fairly determining & $15(5.2)$ & $5(4.5)$ & $10(5.5)$ & \\
\hline Slightly determining & $23(7.9)$ & $8(7.3)$ & $15(8.3)$ & \\
\hline Not determining & $233(80.1)$ & $93(84.5)$ & $140(77.3)$ & \\
\hline
\end{tabular}

a:using the Mann-Whitney U Test.

avoidance of pregnancy was very important. Thus, there were no significant gender differences $(\mathrm{p}=0.954)$. Neither were there differences between sexes with regards to prevention of STIs. This item was also very important for $89.5 \%$ of the women and $86.2 \%$ of the men.

However, for the variable, my demand of a condom, there were gender-based differences $(p=0.002)$. A total of $64.9 \%$ of the female participants regarded this item as highly determining in contrast to $43 \%$ of the male subjects. In the case when the partner requested the use of a condom (partner's demand of a condom), 29.8\% of the women said that the fact that the other person asked to use a condom was slightly determining followed by $34.9 \%$ of the men who regarded it as fairly determining with regard to the consistent use of condoms with casual partners.

In reference to the motives for consistently not using a condom in sexual relations with casual partners (Table 4), there were significant differences between sexes $(\mathrm{p}=0.001)$. For $50 \%$ of the women, the reason, I do not like to use a condom did not influence condom use. However, for $28 \%$ of the men, this reason was very important. Regarding the reason, my partner refused to use one, $44.8 \%$ of the women stated that this factor was not determining, followed by $30.5 \%$ of the men who regarded it as fairly determining or not determining.

However, there were significant differences between sexes for the reason, a condom lessens sensitivity and 
Table 3 Motives for men and women to consistently use condoms in sexual relations with casual partners

\begin{tabular}{|c|c|c|c|c|}
\hline & Total & Females & Males & $\mathrm{P}_{\text {value }} \mathrm{a}$ \\
\hline Avoidance of pregnancy & & & & 0.954 \\
\hline Highly determining & $141(84.9)$ & $49(84.5)$ & $92(85.2)$ & \\
\hline Fairly determining & $15(9)$ & $6(10.3)$ & $9(8.3)$ & \\
\hline Slightly determining & $4(2.4)$ & $2(3.4)$ & $2(1.9)$ & \\
\hline Not determining & $6(3.6)$ & $1(1.7)$ & $5(4.6)$ & \\
\hline Prevention of STIs & & & & 0.565 \\
\hline Highly determining & $145(87.3)$ & $51(89.5)$ & $94(86.2)$ & \\
\hline Fairly determining & $15(9)$ & $4(7)$ & $11(10.1)$ & \\
\hline Slightly determining & $3(1.8)$ & $1(1.8)$ & $2(1.8)$ & \\
\hline Not determining & $3(1.8)$ & $1(1.8)$ & $2(1.8)$ & \\
\hline My demand of a condom & & & & 0.002 \\
\hline Highly determining & $83(50.6)$ & $37(64.9)$ & $46(43)$ & \\
\hline Fairly determining & $37(22.6)$ & $13(22.8)$ & $24(22.4)$ & \\
\hline Slightly determining & $16(9.8)$ & $3(5.3)$ & $13(12.1)$ & \\
\hline Not determining & $28(17.1)$ & $4(7.0)$ & $24(22.4)$ & \\
\hline Partner demand of a condom & & & & 0.107 \\
\hline Highly determining & $38(23.3)$ & $11(19.3)$ & $27(25.5)$ & \\
\hline Fairly determining & $51(31.3)$ & $14(24.6)$ & $37(34.9)$ & \\
\hline Slightly determining & $37(22.7)$ & $17(29.8)$ & 20 (18.9) & \\
\hline Not determining & $37(22.7)$ & $15(26.3)$ & $22(20.8)$ & \\
\hline
\end{tabular}

a:using the Mann-Whitney U Test.

Table 4 Motives for men and women to consistently not use a condom with casual partners

\begin{tabular}{|c|c|c|c|c|}
\hline & Total & Females & Males & $P$ value $^{a}$ \\
\hline I do not like to use a condom & & & & 0.001 \\
\hline Highly determining & $31(22.1)$ & $8(12.8)$ & $23(28)$ & \\
\hline Fairly determining & $31(22.1)$ & $9(15.5)$ & $22(26.8)$ & \\
\hline Slightly determining & $30(21.4)$ & $12(20.7)$ & $18(22)$ & \\
\hline Not determining & $48(34.3)$ & $29(50)$ & $19(23.2)$ & \\
\hline My partners do not like to use a condom & & & & 0.409 \\
\hline Highly determining & 19 (13.6) & $10(17.2)$ & $9(11)$ & \\
\hline Fairly determining & $37(26.4)$ & $12(20.7)$ & $25(30.5)$ & \\
\hline Slightly determining & $33(23.6)$ & $10(17.2)$ & $23(28)$ & \\
\hline Not determining & $51(36.4)$ & $26(44.8)$ & $25(30.5)$ & \\
\hline A condom lessens sensitivity and reduces pleasure & & & & 0.009 \\
\hline Highly determining & $61(44.2)$ & $19(32.8)$ & $42(52.5)$ & \\
\hline Fairly determining & $30(21.7)$ & $12(20.7)$ & $18(22.5)$ & \\
\hline Slightly determining & $22(15.9)$ & $13(22.4)$ & $9(11.2)$ & \\
\hline Not determining & $25(18.1)$ & $14(24.1)$ & $11(13.8)$ & \\
\hline I did not have a condom at the time & & & & 0.235 \\
\hline Highly determining & $47(33.8)$ & $23(39.7)$ & $24(29.6)$ & \\
\hline Fairly determining & $35(25.2)$ & $14(24.1)$ & $21(25.9)$ & \\
\hline Slightly determining & $19(13.7)$ & $7(12.1)$ & $12(14.8)$ & \\
\hline Not determining & $38(27.3)$ & $14(24.1)$ & $24(29.6)$ & \\
\hline
\end{tabular}

a:using the Mann-Whitney U Test. 
reduces pleasure $(p=0.009)$. Thus, for $32.8 \%$ of the female participants and $52.5 \%$ of the male subjects, this was a very important motive for not using condoms. For the reason, I did not have a condom at the time, there were no significant gender-based differences $(p=0.235)$. A total of $39.7 \%$ of the women and $29.6 \%$ of the men regarded this reason as very important in the consistent use of condoms with casual partners.

\section{Discussion}

The results obtained in this study were similar to the findings of previous research $[27,28]$. They identified the existence of an association between gender and high-risk sexual behaviour and practices. A high percentage of male heterosexual, homosexual, and bisexual participants reported sexual intercourse with penetration, and reported a greater number of sexual partners than the female participants. This is consistent with Bermúdez, et al. [29] and López, et al. [30], who highlight that male adolescents are more interested than female adolescents in sexual practices in affective relations. However, in this study, no significant differences were found in the use of condoms in the first sexual relation. This contrasts with previous research [31]. However, the number of men who declared that they had had sex with casual partners was considerably higher. This is consistent with other studies that found that men have a greater tendency to engage in high-risk sexual behaviour [32-34].

With regards to the participants' reasons for having casual sex, our results found that there were significant differences that were gender-based. More specifically, opportunity, interest in knowing the other person, physical excitement, and drug consumption were found to be the main factors in which men and women differed with regard to having sexual relations with casual partners.

In a study of a sample of 423 university students, Piña \& Rivera [35] found that young men who practiced sexual relations with strangers had a social motivation (disinhibition and alcohol or drug consumption). In contrast to the young women, the motivation was biological since they engaged in casual sex because they felt physically excited. These results are consistent with Valdés et al. [36], who found that this high-risk sexual practice is increasingly prevalent among adolescents. In many cases, it is due to a lack of information about the health risks involved. Moreover, in a study of 1559 university students, Robles et al. [37] found the subjects who engaged in casual sex more frequently adduced reasons for not using protection.

The results of our study showed that alcohol consumption was not a determining factor for having sexual relations with casual partners. In contrast, research carried out in other countries (United States, Colombia, and the United Kingdom) [38,39] reported a correlation between alcohol consumption and an increase in high-risk sexual practices in young people. Similarly, studies have also found that when there is the prospect of a sexual encounter, young people may consume drugs in larger quantities and thus could be more disposed to high-risk sexual behaviours $[40,41]$. Consequently, young people may not be aware of the risk involved when they engage in sexual relations under the influence of alcohol or any other drug.

Regarding the use of condoms with casual partners, our results showed significant differences between men and women. The most important reason for using a condom during casual sex was that the partner requested its use during the sexual relation (partner's demand of a condom). These results support those of previous research $[42,43]$. Similarly, in a study of a sample of 3530 university students, Ballester et al. [44] concluded that the young women perceived themselves as having a higher level of self-efficacy. In this context, this means that they had greater belief in their decision-making capacity with regards to condom use. In contrast, men only felt more competent when it was a question of purchasing condoms.

The main factors that motivated the non-use of condoms in casual sex were I do not like to use a condom and a condom lessens sensitivity and reduces pleasure. In fact, this last reason was considered to be very important for $32.8 \%$ of the women and $52.5 \%$ of the men. These results support the data collected in other studies [45]. The non-use of condoms may or may not vary, according to gender as found in previous research $[46,47]$.

Similarly, Dávila et al. [48] state that the motives for condom use can interfere with preventive behaviours. Fierros et al. [49] studied sexual activity with casual partners in a sample population of university students. They found that the female participants continued to practice high-risk sexual behaviours that could lead to an HIV infection since there was little possibility of their adopting protective measures with casual partners with whom they were barely acquainted. Feelings of attraction and momentary physical excitement prevented the women from engaging in protected sex.

\section{Limitations of the study}

The main limitations of this study were its cross-sectional nature combined with the lack of data with regard to the training received by the participants and their sexual knowledge. Other important limitations were the small size of the sample and the collection of information by selfreporting, especially in reference to such a delicate topic. In future research it will be necessary to take into account the multicultural identity of the territory since this could determine conclusions in relation to sexual tendencies.

\section{Conclusions}

Men and women engage in high-risk sexual practices and behaviours for very diverse reasons. It is necessary 
to consider these reasons in the design and implementation of preventive measures. Concerning the motives for having sexual relations with casual partners, male participants considered opportunity and interest in knowing the other person to be more important than the female participants. Regarding condom use, the female subjects' demand of condom use was a significant gender-based difference. In contrast to the young women, the male participants mostly justified not using a condom because it lessened sensitivity and reduced pleasure. There are similarities between the results obtained in this study and those of other studies of sexual partners and gender. However, concerning motives for engaging in sexual relations, the results of previous research are far from uniform. In this sense, health promotion programs in education centers should recommend and sponsor activities that make young people aware of the need to use condoms in sexual contacts. In this sense, it is necessary to continue working to eradicate high-risk sexual behaviour and to foment a more equal, satisfying, and safer sexuality. Future research will evaluate the impact of educational programs on young people and their sexual behaviour.

\section{Abbreviations}

HIV: Human immunodeficiency virus; STI: Sexually transmitted infections; UNED: National Distance Education University; INE: National Institute of Statistics.

\section{Competing interests}

The authors declare that they have no competing interests.

\section{Authors' contributions}

ER-E designed and conducted the study. IG-G performed the statistical analyses. EG-J drafted the manuscript. All authors interpreted the results. MCM-F and IG-G critically revised the manuscript. All authors read and approved the final manuscript.

\section{Acknowledgements}

We are grateful to schools students, university students, and members of the armed forces for their collaboration in the development of this study. This study did not receive financing for its development.

\section{Author details}

'Department of Nursing, Faculty of Nursing, C/ Santander N ${ }^{\circ} 1$ (52071), University of Granada, Melilla, Spain. ${ }^{2}$ Department of Evolutionary Psychology and Education, Faculty of Education Science, Campus Universitario de La Cartuja, s/n (18071), University of Granada, Granada, Spain. ${ }^{3}$ Department of Nursing, Faculty of Health Sciences, Av/ Madrid s/n (18071), University of Granada, Granada, Spain

Received: 24 February 2014 Accepted: 17 July 2014

Published: 23 July 2014

\section{References}

1. Rangel Flores YY, García Rangel M: Influence of gender role on the sexual behavior of university students. Index Enferm 2010, 19. http://dx.doi.org/ 10.4321/S1132-12962010000300003.

2. García-Vega E, Menéndez Robledo E, García Fernández P, Rico-Fernández R: Influencia del sexo y del género en el comportamiento sexual de una población adolescente. Psicothema 2010, 22:606-612.

3. Petersen JL, Hyde JS: A meta-analytic review of research on gender differences in sexuality, 1993-2007. Psychol Bull 2010, 136:21-38.
4. Maté C, Acarín N: Encuesta sobre la elección de pareja a estudiantes de la Universitat Pompeu Fabra, Barcelona (20 a 27 años). Summa Psicológica UST 2011, 8:37-46.

5. Larrañaga $E$, Yubero $S$, Yubero M: Influencia del género y del sexo en las actitudes sexuales de estudiantes universitarios españoles. Summa Psicológica UST 2012, 9:5-13.

6. Falah-Hassani K, Kosunen E, Shiri R, Rimpelä A: Emergency contraception among Finnish adolescents: awareness, use and the effect of nonprescription status. BMC Public Health 2007, 7:201.

7. Hooke L, Capewel S, Whyte M: Gender differences in Ayrshire teenagers attitudes to sexual relationships, responsibility and unintended pregnancies. J Adolesc 2000, 23:477-486.

8. Fernández AM, Celis-Atenas K, Córdova-Rubio N, Dufe M, Corrêa MA, Benedetti $J H$ : Sexualidad juvenil: prácticas, actitudes y diferencias según sexo y variables de personalidad en universitarios chilenos. Rev Med Chil 2013, 141:160-166.

9. García-Carpintero A, Gonçalves R, Dutra A: Conductas sexuales en el cotidiano de adolescentes y jóvenes de la cultura hip hop. Texto Contexto Enfermería Florianópolis 2014, 23:126-133.

10. Rodríguez Carrión J, Traverso Blanco Cl: Conductas sexuales en adolescentes de 12 a 17 años de Andalucía. Gac Sanit 2012, 26:519-526.

11. Ping Wong L: An exploration of knowledge, attitudes and behaviours of young multiethnic Muslim-majority society in Malaysia in relation to reproductive and premarital sexual practices. BMC Public Health 2012, 12:865.

12. Lepusić D, Radović-Radovcić S: Alcohol a predictor of risky sexual behavior among female adolescents. Acta Clin Croat 2013, 52:3-9.

13. Planes M, Gras M, Soto J: Comportamiento anticonceptivo en estudiantes universitarios y riesgo de infección con el virus de inmunodeficiencia humana (VIH). Anuario de Psicología 2002, 33:97-110.

14. Chandra-Mouli V, McCarraher DR, Phillips SJ, Williamson NE, Hainsworth G: Contraception for adolescents in low and middle income countries: needs, barriers, and access. Reprod Health 2014, 11:1. doi:10.1186/17424755-11-1.

15. Fernández-Dávila P, Zaragoza Lorca K: Hombres jóvenes que tienen sexo con hombres: ¿un colectivo en alto riesgo para la infección por el VIH? Gac Sanit 2012, 25:372-378.

16. Martínez J, Maya NA, Parada L, Duarte K: Diferencias de las prácticas sexuales entre hombres y mujeres universitarios. Duazary Revista de la Facultad de Ciencias de la Salud 2013, 10:112-118.

17. World Health Organization, UNAIDS: Sexually transmitted diseases: policies and principles for prevention and care. Geneva: WHO; 1997.

18. Klein H: Sexual orientation, drug use preference during sex, and HIV risk practices and preferences among men who specifically seek unprotected sex partners via the internet. Int J Environ Res Pub Health 2009, 6:1620-1635

19. Forhan SE, Gottlieb SL, Sternberg MR, Xu F, Datta SD, McQuillan GM Berman SM, Markowitz LE: Prevalence of sexually transmitted infections among female adolescents aged 14 to 19 in the United States. Pediatrics 2009, 124:1505-1512.

20. Instituto Nacional de Estadística: Casos acumulados de Sida (1) desde 1981 hasta 30 de Junio de 2012 por CCAA de residencia, categoría de transmisión (2) y sexo. Accessed on 3 mayo 2014 at http://www.ine.es/jaxi/tabla.do.

21. Ministerio de Sanidad y Política Social e Igualdad: Interrupción Voluntaria del Embarazo. Datos definitivos correspondientes al año 2012. Accessed on 6 mayo 2014 at: http://www.msssi.gob.es/profesionales/saludPublica/ prevPromocion/docs/publicacionIVEcompleto_2009.pdf.

22. Thin Zaw PP, Liabsuetrakul T, McNeil E, Htay TT: Gender differences in exposure to SRH information and risky sexual debut among poor Myanmar youths. BMC Public Health 2013, 13:1122.

23. Instituto Nacional de Estadística: Estadística del Padrón continúo. Datos provisionales a 1 de enero de 2013. Available at: http://www.ine.es/jaxi/ tabla.do.

24. Instituto Nacional de Estadística: Población por edad (grupos quinquenales) y sexo. Available at: http://www.ine.es/jaxi/tabla.do.

25. Piña JA, Robles S, Rivera BM: Instrumento para la evaluación de variables psicológicas y comportamientos sexuales de riego en jóvenes de dos centros universitarios de México. Revista Panamericana de Salud Pública 2007, 22:295-303.

26. Ribes E: Psicología y salud. Un análisis conceptual. Barcelona: Martínez Roca; 1990. 
27. Bermúdez MP, Ramiro-Sánchez T, Ramiro MT: Capacidad predictiva de la erotofilia y variables sociodemográficas sobre el debut sexual. Revista Iberoamericana de Psicología y Salud 2014, 5:55-70.

28. Dunkle KL, Decker MR: Gender-based violence and HIV: Reviewing the evidence for links and causal pathways in the general population and high-risk groups. Am J Reprod 2013, 69:20-26.

29. Bermúdez M, Teva I, Buela-Casal G: Influencia de variables sociodemográficas sobre los estilos de afrontamiento, el estrés y la búsqueda de sensaciones sexuales en adolescentes. Psicothema 2009, 21:220-226.

30. López F, Carcedo R, Fernàndez-Rouco N, Blázquez M, Kilani A: Diferencias sexuales en la sexualidad adolescente: afectos y conductas. Anales de Psicología 2011, 27:791-799.

31. Dávila Tapia M, Piña López JA: Characterization, predictors of risk sexual behaviors, and condom use among university women. Enseñanza e Investigación en Psicología 2008, 13:279-299.

32. Amado MA, Vega BR, Jiménez MC, Piña JA: Factores que influyen en el uso de preservativo en mujeres en edad reproductiva de Tunja, Colombia. Acta Colombiana de Psicología 2007, 10:143-151.

33. Sayles JN, Pettifor AE, Wong MD, MacPhail C, Lee SJ, Hendriksen E, Rees HV, Coates T: Factors associated with self-efficacy for condom use and sexual negotiation among South African youth. J Acquir Immune Defic Syndr 2006, 43:226-233.

34. Teva I, Bermúdez M, Buela-Casal G: Búsqueda de sensaciones sexuales, estilos de afrontamiento, estrés social y su relación con la conducta sexual adolescente. Anales de Psicología 2011, 27:35-46.

35. Piña López JA, Rivera Icedo M: Predictores del comportamiento sexual con múltiples parejas en estudiantes de educación superior: un análisis por género. Acta Colombiana de Psicología 2009, 12:53-65.

36. Valdés García LE, Malfrán García MD, Ferrer Savigne Y, Salazar Aguilera E: Knowledge, attitudes and sexual practices in Santiago de Cuba province. MEDISAN 2012, 16:1-13.

37. Robles S, Montijo D: Evaluación de prácticas sexuales de riesgo en estudiantes universitarios. In La psicología social en México, Volume VII. Mexico: AMEPSO; 2000:748-755.

38. Rodríguez A, Hernán M, Cabrera A, Romo N, García JM, Gutiérrez JL: ¿Tienen adolescentes y jóvenes que consumen drogas no inyectadas mayor probabilidad de transmisión sexual del VIH? Adicciones 2006, 18:61-72.

39. Bellis M, Hughes K, Dillon P, Copeland J, Gates P: Effects of backpacking holidays in Australia on alcohol, tobacco and drug use of UK residents. BMC Public Health 2007, 7:1-20.

40. Elliott L, Morrison A, Ditton J, Farrall S, Short E, Cowan L, Gruer L: Alcohol, drug use and sexual behaviour of young adults on a Mediterranean dance holiday. Addict Res 1998, 6:319-340.

41. Brook DW, Brook JS, Pahl T, Montoya I: The longitudinal relationship between drug use and risky sexual behaviors among Colombian adolescents. Arch Pediatr Adolesc Med 2002, 156:1101-1107.

42. Tran BR, Thomas AG, Ditsela M, Vaida F, Phetogo R, Kelapile D, Chambers C, Haubrich R, Shaffer R: Condom use behaviours and correlates of use in the Botswana Defence Force. Int J Std Aids 2013, 24:883-892.

43. Staras SA, Livingston MD, Maldonado-Molina MM, Komro KA: The influence of sexual partner on condom use among urban adolescents. J Adolesc Health 2013, 53:742-748.

44. Ballester R, Gil-Llario MD, Ruiz-Palomino E, Giménez-García C: Autoeficacia en la prevención sexual del Sida: la influencia del género. Anales de Psicología 2013, 29:76-82.

45. Maswanya ES, Moji K, Aoyagi K, Takemoto T: Sexual behavior and condom use in female students in Dar-es-Salaam, Tanzania: differences by steady and casual partners. East Afr J Pub Health 2011, 8:69-76.

46. Uribe RF, Valderrama L, Sanabria AM, Orcasita L, Vergara T: Descripción de los conocimientos, actitudes y autoeficacia frente al VIH/Sida en un grupo de adolescentes colombianos. Pensamiento Psicológico 2009, 12:29-43.

47. Uribe Jl, Amador G, Zacarías X, Villarreal L: Percepciones sobre el uso del condón y la sexualidad entre jóvenes. Revista Latinoamericana de Ciencias Sociales, Niñez y Juventud 2012, 10:481-494.
48. Piña JA, Lozano I, Vázquez P, Carrillo IC: Motivos y uso de preservativo en estudiantes universitarios de Ciudad Juárez (México). Anales de Psicología 2010, 26:18-26.

49. Fierros LE, Rivera BM, Piña JA: Sexual behavior with casual partners among university women. Revista Iberoamericana de Psicología y Salud 2011, 2:165-183.

doi:10.1186/1471-2458-14-745

Cite this article as: Romero-Estudillo et al:: Gender-based differences in the high-risk sexual behaviours of young people aged 15-29 in Melilla (Spain): a cross-sectional study. BMC Public Health 2014 14:745.

\section{Submit your next manuscript to BioMed Central and take full advantage of:}

- Convenient online submission

- Thorough peer review

- No space constraints or color figure charges

- Immediate publication on acceptance

- Inclusion in PubMed, CAS, Scopus and Google Scholar

- Research which is freely available for redistribution

Submit your manuscript at www.biomedcentral.com/submit
C Biomed Central 